\title{
Enhancing Production of Potato (Solanum tuberosum L.): Evidence from Demonstration and Participatory Evaluation of Improved Potatoes in Kellam and West Wollega Zones
}

\author{
Bilisuma Kabeto* Hika Tesfa Demaksa Umer \\ Oromia Agricultural Research Institute, Haro Sabu Agricultural Research Center, \\ P.O. Box. 10, Haro Sabu, Ethiopia
}

\begin{abstract}
Selection of appropriate varieties and quality seed to be planted is the most important steps in boosting agricultural production; failures to do so would result in loss of yield or market acceptability of crops. To ensure this demonstration of improved potato varieties were conducted in West and Kellam Wollega Zones of Oromia national regional state. Different participatory technology evaluations were employed to enable farmers to select the variety/varieties which fit their local conditions based on their own preference. The result obtained indicated that, the production of Belete variety can increase potato production by $56.26 \%$ and Gudane can increase potato production by $49.95 \%$ in Zones compared to the local practice. More importantly, farmers were enabled to select varieties based on their own criterion, Accordingly, the direct matrix ranking indicated Belete variety as their first choice with the total percentage of $42.32 \%$, Gudane and Local second and third with total percentage of $38.62 \%$ and $19.05 \%$ respectively. Besides, the profitability analysis indicated higher profit was obtained from Belete variety followed by Gudane. Therefore, based on the agronomic yield under farmers' management conditions and farmers' preference to the varieties, extension service providers and other concerned bodies should give attention to increasing the adoption of improved Belete and Gudane varieties in the target areas to boost potato production.
\end{abstract}

Keyworlds: Belete; Demonstration; Gudane; Pair wise ranking; Potato.

DOI: $10.7176 / \mathrm{FSQM} / 110-01$

Publication date:September $30^{\text {th }} 2021$

\section{Back ground and Justification}

Potato (Solanum tuberosum L.) is the world's most important root and tuber crop. It is grown in more than 125 countries and consumed almost daily by more than a billion people (Teshome, 2016). In 2005, the developing countries' share of global potato output stood at 52 percent, surpassing that of the developed world which was a remarkable achievement and developing countries are now the world's biggest potato producers and importers at the same time consumer demand is shifting from fresh tubers to processed product (FAO, 2008a). Over half of all production occurs in developing countries (Devaux et al., 2014), with nearly 400 million tons produced worldwide every year, leading to stability in food supply and socio-economic impact (Halter man et al. 2016). Potatoes is important staple and cash crop in sub-Saharan Africa's highland zones, and Uganda is a major potato producer in the region with over 60 percent of the national crop (FAO, 2008b). Ethiopia is one of the principal potatoes producing countries in Africa and probably displays a unique position for having the highest potential area for cultivating potatoes. It is endowed with suitable climatic and edaphic condition for the production of high yield of potatoes (Alo and Geremew, 2021).

Once harvested potato can be the used in variety of purposes: as fresh vegetables for cooking in the house, as raw material for the industries, and as feed for the animals (Lupescu and Zimmerman, 2015). However, in Ethiopia consumption of potato is limited to small chips making and cooking due to limited knowhow of the households (Emana and Nigussie, 2011).

In Ethiopia and Kenya the quality of potato seed used for production is very low, the outcome which is limited productivity below the potential (Mumia et al., 2018; Emana \& Nigussie, 2011). The major problems associated with potato production were; concentration of potato cultivation in the highlands, unavailability and high cost of seed tubers and less quality seed, non-optimal agronomic practices, the prevalence of diseases and insect pests, and inadequate storage, transportation and marketing facilities (MoA, 2018)

Nowadays to remove the barriers associated with improved varieties and seed quality many improved potato varieties have been released by research centers and universities for production in Ethiopia. These improved potato varieties together with improved management proved to give three-to-four-fold yield advantage as compared to local varieties together with traditional production and management practices. Therefore, introduction and testing of improved potato technologies to specific areas involving farmers' participation will help identify best fit technologies to the existing production system that can ensure sustainable food (Asresie et al., 2015).

The Western part of Oromia, with suitable Agro ecology for Potato production is limited with the 
accessibility to improved variety and potato seed preparing mechanism. To reduce the barriers associated with potato production and helps farmers in accessing the technology and enhance the production of potato, a demonstration of potato technology with full package was conducted in West and Kellam Wollega Zones.

\subsection{Objectives}

$>$ To demonstrate and evaluate the productivity and profitability of Potato under farmers' management practices.

$>$ To bring synergy among researchers, Extension agents, farmers and other stalk holders in deciding strategies of popularization of improved potato technologies.

$>$ To create awareness on potato production package

\section{Methodology}

\subsection{Description of the study area}

Seyo

Seyo district is located in the South Western part of Kellam Wollega zone. Astronomically the district is located between $8^{0} 12^{\prime}-8^{0} 44^{\prime} \mathrm{N}$ and $34^{0} 41^{\prime}-35^{\circ} 00^{\prime} \mathrm{E}$. The district generally lies within an altitudinal range of 1300 2000masl. The major rainy seasons in the district include spring (April-May), summer (June-August) and autumn (September-November).

\section{L/Asabi district}

The district is located in West Wollega Zone of Oromia national regional state at the distance of $23 \mathrm{~km}$ to West of Zonal capital Ghimbi. Astronomically the district lies between the coordinate of $9^{\circ} 5^{\prime} 0^{\prime \prime} \mathrm{N}, 35^{\circ} 50^{\prime} 0^{\prime \prime} \mathrm{E}$. The topography of the district is characterized by ups and down trains with the altitude range of 1500-1900masl. The agroecology of the district falls with the range of midland agroecology with annual average rainfall of $1737.5 \mathrm{~mm}$ year ${ }^{-1}$.

\subsection{Site and Farmers Selection}

Two AGP-II beneficiary districts, one district from each zone (West and Kellam Wollega zones) were selected purposively based on being AGP-II beneficiary district, access to transport service and potato production potential. These districts were L/Asabi and Seyo. From each district, two representative model kebeles were selected based on their potential for potato production and accessibility.

The FRG (Farmer Research Group) was established in each operational kebeles. The FRG formed was gender inclusive (male, female and youth group).

Before starting the field work, selection of experimental farmers was done in collaboration with researchers, extension agents and FRG members by taking in to consideration the farmers' interests and motivation, land ownership, and other important socio-economic aspects

Table1: - Composition of FRG member

\begin{tabular}{llllllll}
\hline No & District & Kebeles & Number of FRGs & \multicolumn{2}{c}{ Member of FRGs } & \multicolumn{2}{c}{ Trial farmers } \\
\hline & & & & Male & Female & Male & Female \\
\hline 1 & Seyo & Tabor & 2 & 20 & 12 & 5 & 1 \\
& & H/Karo & 1 & 16 & 4 & 3 & 0 \\
2 & L/Asabi & A/Serdo & 2 & 28 & 4 & 4 & 1 \\
& & G/Siban & 1 & 14 & 6 & 3 & 0 \\
\multirow{2}{*}{$\begin{array}{l}\text { Total } \\
\text { Percentage }\end{array}$} & & 6 & 78 & 26 & 15 & 2 \\
\hline
\end{tabular}

\subsection{Materials used}

Three varieties of potatoes namely Belete, Gudane and Local were used for this demonstration trial with recommended fertilizer rate of NPS $195 \mathrm{~kg} \mathrm{ha}^{-1}$ and Urea $165 \mathrm{~kg} \mathrm{ha}^{-1}$.

\subsection{Field design}

The trial was carried out on selected farmer's fields in such a way that three varieties were planted side by side on equal sized plots of $10 \mathrm{~m} \times 10 \mathrm{~m}$ with a gross area of $100 \mathrm{~m}^{2}$. Sowing was done with spacing of $75 \mathrm{~cm}$ between rows and $30 \mathrm{~cm}$ between tubers.

\subsection{Technology evaluation and demonstration methods}

Different methods were employed to create awareness and evaluate demonstrated Potato varieties. Among the method used training, different PRA tools like pair wise ranking, participatory technology demonstration and evaluation and direct matrix ranking were employed. 


\subsection{Method of data collection and analysis}

Data were collected through observation of the field, checklist and focused group discussion. The collected data were analyzed using SPSS version 22 and illustration graph were done using sigma plot version 10.

\section{Result and discussion}

\subsection{Yield performance of demonstrated potato varieties}

The result obtained indicated that yield performance of Belete superiority over others varieties. This improved variety with improved management practices gave a tuber yield of 34.69-ton ha ${ }^{-1}$ followed by Gudane with magnitude of 33.29-ton ha ${ }^{-1}$ (figure 1). The local variety with improved management practices gave 22.2 ton ha ${ }^{-1}$. This is in line with the study of (Tessema et al., 2020; Jafar et al., 2020; Alo and Geremew, 2021; Hailu et al., 2020; Kassaw et al., 2021; Alo and Geremew, 2021b; Befikadu et al., 2019) which reported Belete superiority over other varieties. The yield of Belete was $26 \%$ lower of its potential yield (figure 1). The yield advantage of Belete and Gudane over the local variety which farmers were producing was $56.26 \%$ and $49.95 \%$ respectively. This could double the amount of potato production in West and Kellam Wollega Zones. The yield of Belete showed significant difference the district, while Gudane and local showed no significant difference (figure 2). The biggest tuber size $\left(\mathrm{cm}\right.$ plant $\left.^{-1}\right)$ was obtained from Belete variety, it was higher by $12.5 \%$ and $39.70 \%$ over Gudane and Local respectively (figure 3), coinciding with Jafar et al., 2020. The highest number of marketable tubers was obtained from Gudane variety with mean value of 13.92 followed by Belete and Local with magnitude of 11.91 and 10.35 respectively (figure 4). However Jafar et al., 2020 reported higher number of marketable tuber for Gudane variety compared to other varieties. This difference could be attribute to the agro ecological and soil fertility difference between the locations.

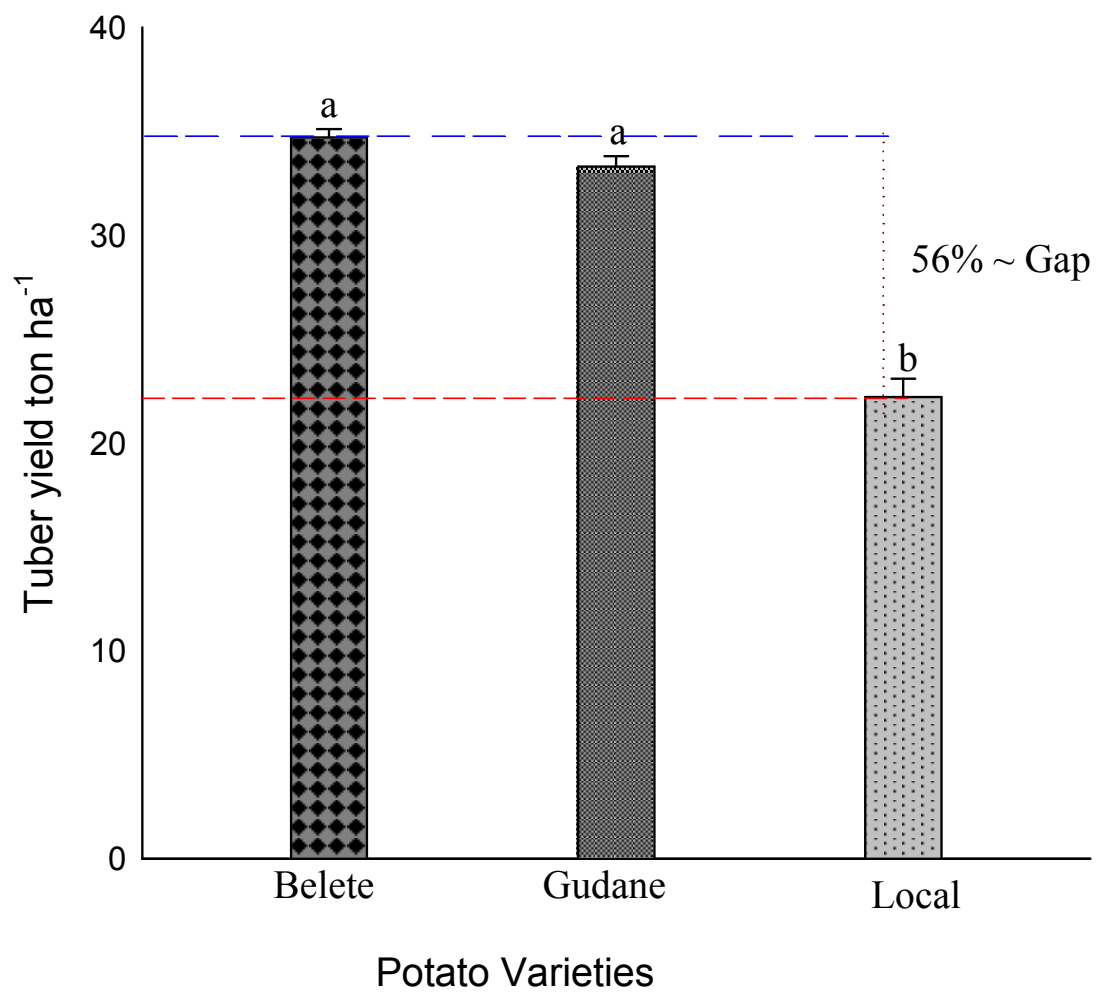

Figure 1. Yield performance of demonstrated varieties. Each value was the mean yield of 17 trial farmers. Different lower case denotes significant difference $(\mathrm{P}<0.05)$ among varieties. 


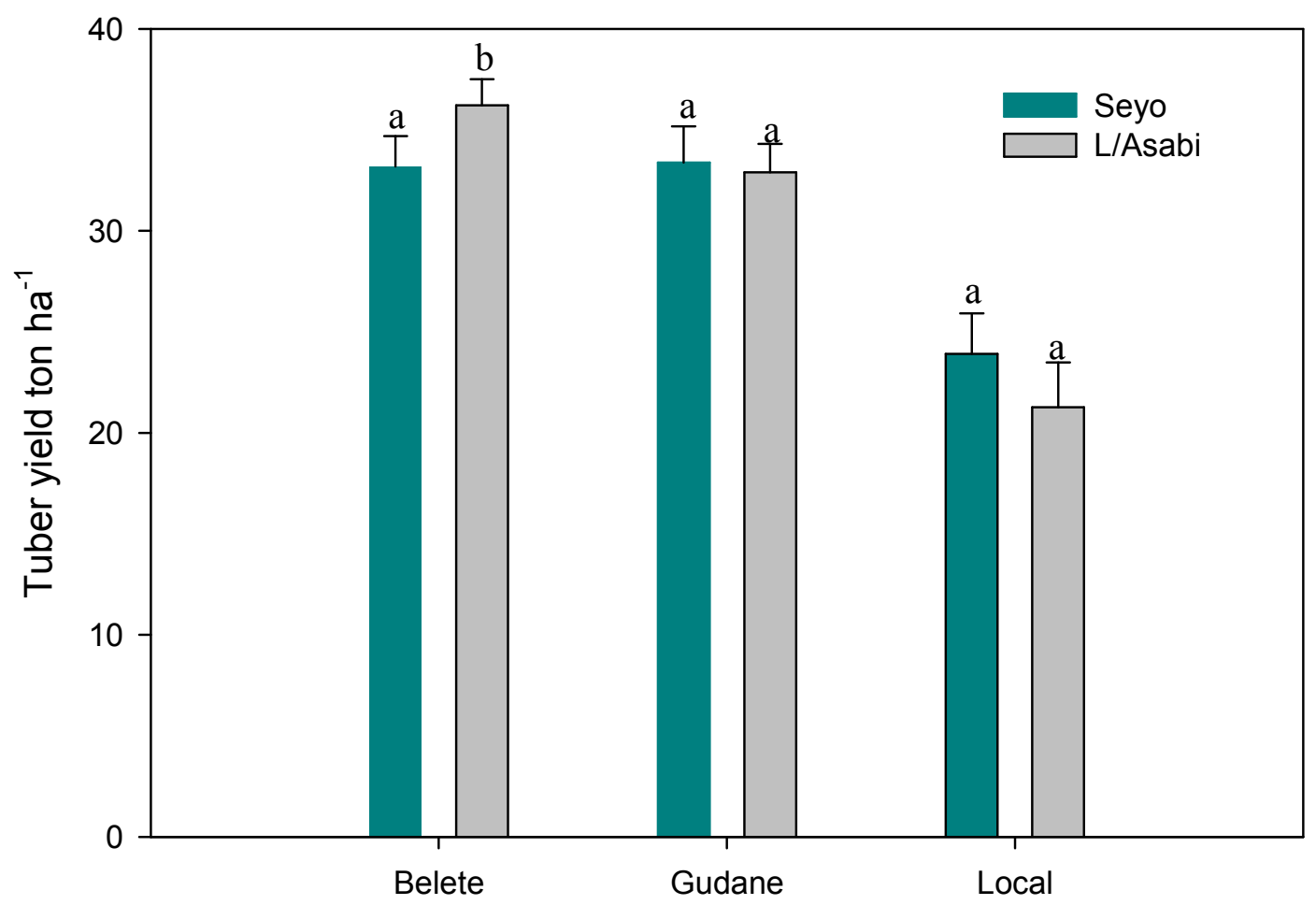

Figure 2. Yield performance over location. Each value was the mean yield of tuber at trial farmer's field. Different lower case denotes significant difference $(\mathrm{P}<0.05)$ between the two locations of the same variety.

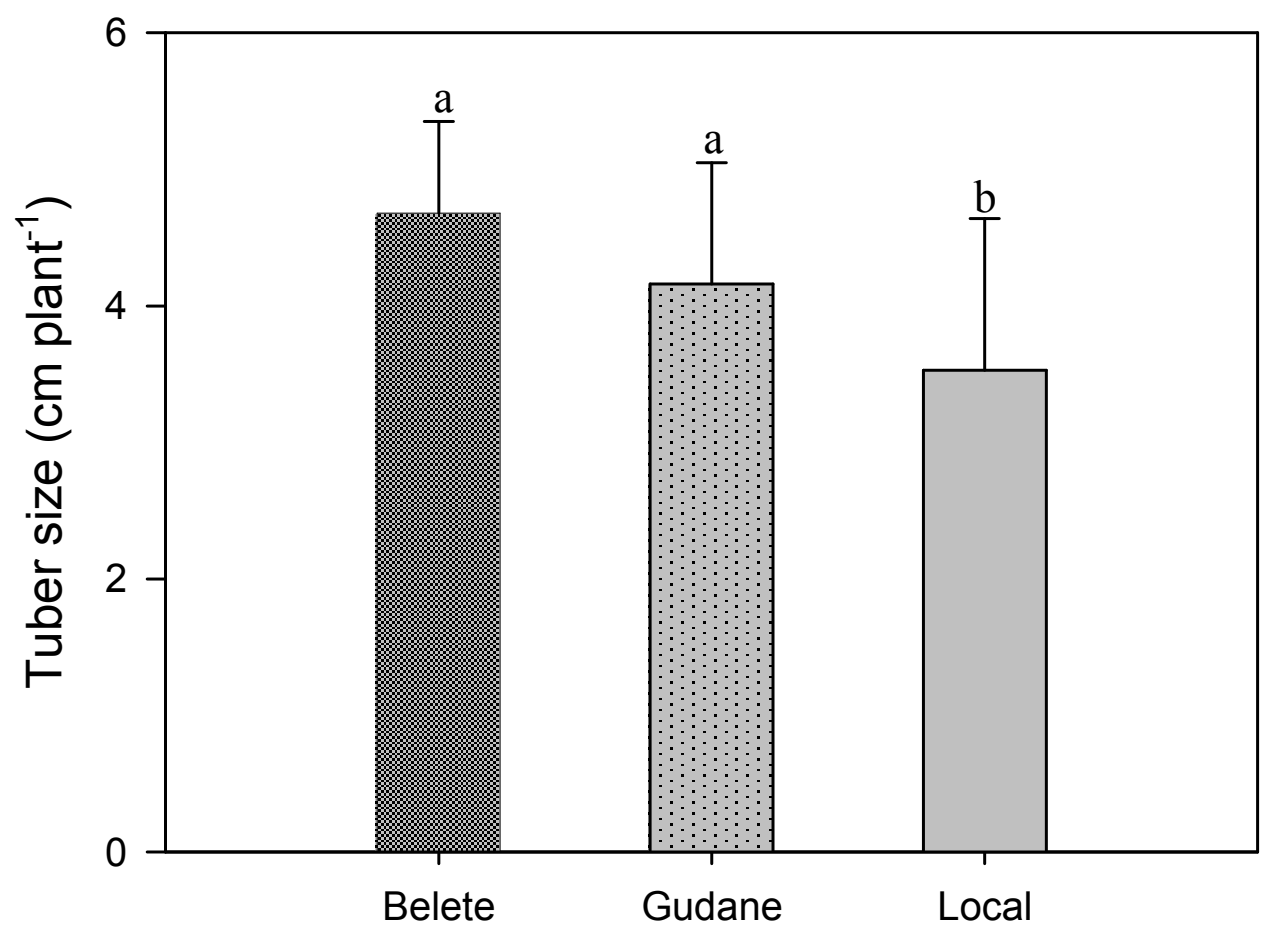

Figure 3. Tuber size per plant. Each value was the mean of 17 trial farmers. Different lower case denotes significant difference $(\mathrm{P}<0.05)$ among varieties. 


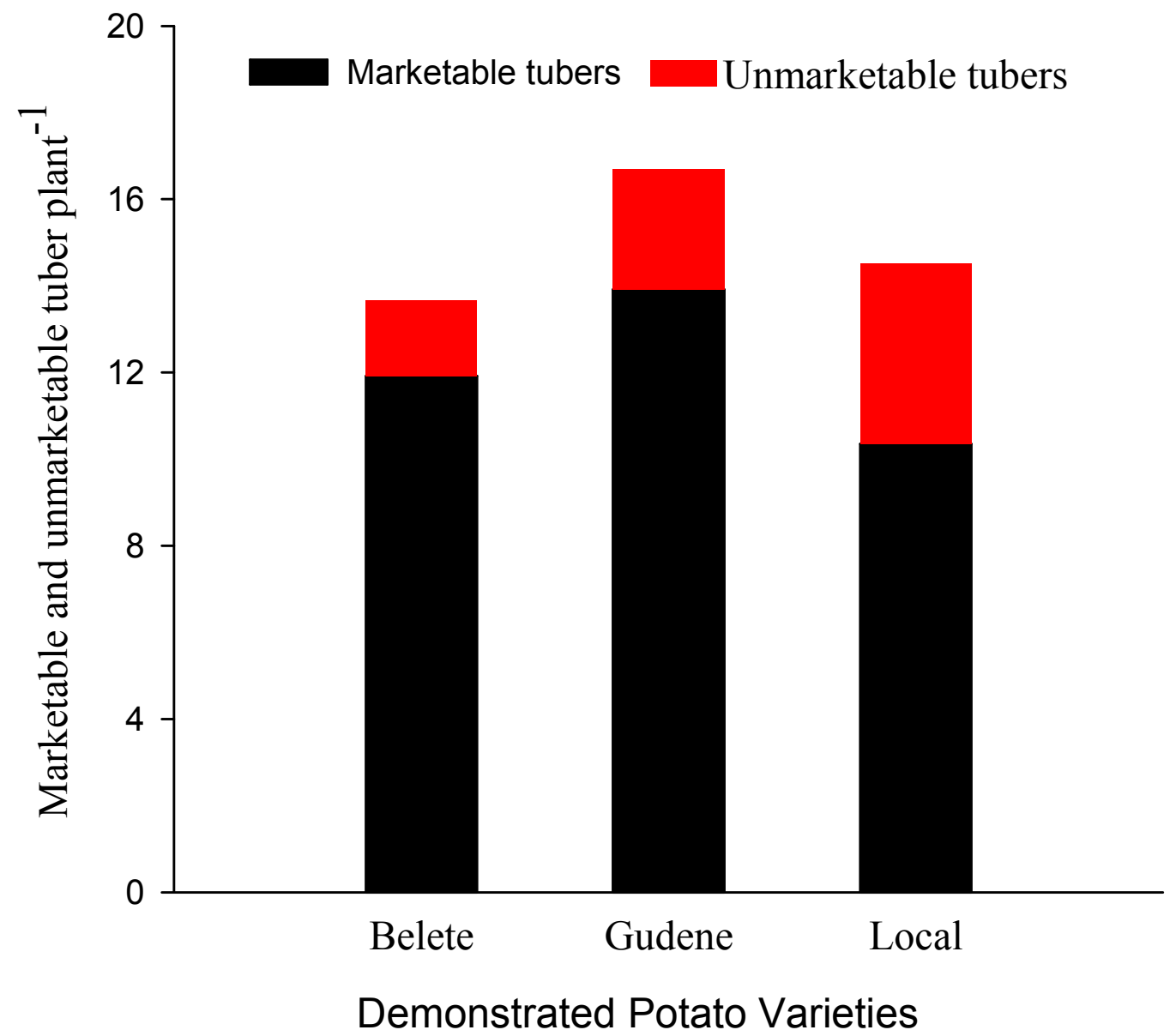

Figure 4. Numbers of marketable and unmarketable tubers per plant. Each value was the mean of 17 trial farmers

\subsection{Participatory varietal selection and farmers' preference of variety traits.}

One of the most important parts of this demonstration was evaluation, selection and preference of farmers to demonstrated potato varieties. Farmers are strongly inclined to their likeness and dis- likeness (preference) to improved agricultural technologies. This preference will help them to give up less favored variety/crop and adopt favored variety/crop. This will in turn help the breeders to develop the desired quality traits of particular crop the outcome which is enhancing the rate of adoption of technologies as well reduce time and energy. Accordingly, different stakeholders participated on evaluation of these varieties at different time and selected the best trait of varieties according to their importance to them. Accordingly, a total of 126 (46 Female and 80 male) stake holders evaluated and selected varieties based on their own criteria. These criterions were: -Tuber yield, Disease tolerance, Tuber size, Cooling quality, Marketability and Early maturity. The research conducted by Asresie et al., 2015 reported Belete superiority for its yield, disease and insect tolerance, maturity, cooking quality and adaptability. Again Belete variety was selected as top variety by stakeholder by their own criteria (Merga and Dechassa, 2019; Jafar et al., 2020; Kolech et al., 2015).

Table 2. Pair wise ranking of varieties

\begin{tabular}{lllllllll}
\hline Traits & TY & DT & TS & CQ & MR & EM & Frequency & Rank \\
TY & X & DT & TY & TY & TY & TY & 4 & 2 \\
DT & & X & DT & DT & DT & DT & 5 & 1 \\
TS & & & X & CQ & MR & TS & 1 & 5 \\
CQ & & & & X & MR & CQ & 2 & 4 \\
MR & & & & X & MR & 3 & 3 \\
EM & & & & & X & - & \\
\hline
\end{tabular}

Note: $\mathrm{TY}=$ Tuber yield, $\mathrm{DT}=$ Disease tolerance, $\mathrm{TS}=$ Tuber size, $\mathrm{CQ}=\mathrm{Cooling}$ quality, $\mathrm{MR}=\mathrm{Marketability,} \mathrm{EM}=$ Early maturity. 
Table 3. Direct matrix ranking of varieties

\begin{tabular}{|c|c|c|c|c|}
\hline \multirow[t]{2}{*}{ No } & \multirow[t]{2}{*}{ Criteria $(\mathrm{N}=126)$} & \multicolumn{3}{|c|}{ Farmers Preference and ranking of potato Varieties } \\
\hline & & Belete & Gudane & Local \\
\hline 1 & Disease Tolerance & 71 & 55 & - \\
\hline 2 & Tuber yield & 64 & 62 & - \\
\hline 3 & Tuber Size & 67 & 59 & - \\
\hline 4 & Cooling Quality & 41 & 35 & 50 \\
\hline 5 & Marketability & 41 & 41 & 44 \\
\hline \multirow[t]{4}{*}{6} & Early Maturity & 36 & 40 & 50 \\
\hline & Total & 320 & 292 & 144 \\
\hline & percentage & $42.32 \%$ & $38.62 \%$ & $19.05 \%$ \\
\hline & Rank & 1 & 2 & 3 \\
\hline
\end{tabular}

As shown in the above table farmers preferred and selected Belete variety as their first preference by all criteria of their choice followed by Gudane and local. Generally, farmers preferred and ranked Belete variety first with the total percentage of $42.32 \%$, Gudane and Local second and third with total percentage of $38.62 \%$ and $19.05 \%$ respectively. Similarly, Belete variety was selected first for its tolerance to disease, higher yield over other six varieties demonstrated in Amhara region (Asresie et al 2015) and Gudane was selected as the good cooking quality by the study conducted by Hailu et al., 2020. Kassaw et al., 2021 also reported the Belete variety was the best in terms disease tolerance especially late blight disease.

Table 4. Profitability analysis

\begin{tabular}{|c|c|c|c|c|c|c|}
\hline \multirow[t]{2}{*}{ No } & \multirow[t]{2}{*}{ Items } & \multirow[t]{2}{*}{ Description } & \multirow[t]{2}{*}{ Quantity } & \multicolumn{3}{|c|}{ Variety } \\
\hline & & & & Belete & Gudane & Local \\
\hline 1 & Average yield & & - & 346.85 & 330.29 & 221.81 \\
\hline 2 & Adjusted yield (-10\%) & & & 312.17 & 297.26 & 199.79 \\
\hline \multicolumn{2}{|r|}{ Total revenue (gain) } & & & 156085 & 148630 & 99855 \\
\hline 3 & Seed cost & & 2 ton & 20000 & 16000 & 10000 \\
\hline \multirow[t]{3}{*}{4} & \multirow[t]{3}{*}{ Fertilizer cost in $\mathrm{Kg}$} & NPS & $195 \mathrm{Kg}$ & 3122.145 & 3122.145 & 3122.145 \\
\hline & & Urea & $165 \mathrm{Kg}$ & 2428.305 & 2428.305 & 2428.305 \\
\hline & & Total & & 5550.45 & 5550.45 & 5550.45 \\
\hline 5 & Land preparation & Oxen or tractor $/ \mathrm{ha}$ & & 4000 & 4000 & 4000 \\
\hline \multirow[t]{4}{*}{6} & Labor cost per day & Sowing & 20 & 1000 & 1000 & 1000 \\
\hline & & Hilling and Weeding & 40 & 2000 & 2000 & 2000 \\
\hline & & Harvesting and transportation & 60 & 3000 & 3000 & 3000 \\
\hline & & Chemical application & 6 & 300 & 300 & 300 \\
\hline 7 & Cost of chemical & Ridomil gold (kg) & 2.5 & 5000 & 5000 & 5000 \\
\hline 8 & Opportunity cost of land & hectare & 1 & 4000 & 4000 & 4000 \\
\hline 9 & Total Cost & & & 50400.9 & 46400.9 & 40400.9 \\
\hline 10 & Net benefit & TR-TC & & 105684.1 & 102229.1 & 59454.1 \\
\hline
\end{tabular}

Note: Cost were in Ethiopian Currency (1 USD $=32.084$ ETB) Computed in January 2020

The net benefit that was gained from producing Belete variety was higher than the one that obtained from producing Gudane and local. The actual values obtained from each variety were 105684.1, 10229.1 and 68454.1 ETB for Belete, Gudane and Local respectively. This manifest that producing Belete variety makes more net benefit to farmers over Gudane and Local by the percent of $3.26 \%$ and $43.74 \%$ respectively.

\subsection{Lesson learned}

It is undeniable fact that farmers do have best indigenous knowledge of their environment and farming practice. Thus, demonstration of these potato varieties gave farmers, Researchers and agricultural experts considerable knowledge of potato production in different ways. Farmers aware and identified and selected/preferred potato variety which suited their actual condition while researchers got farmers preference to different traits of potato technologies which will provide the base for future technology generation.

Practical training that focused on agronomic practices, quality seed tuber, integrated disease management and postharvest handling techniques were given to the FRG members, development agents (DA) and to 
Agricultural experts of each district. The training sessions were aimed at facilitating and assisting farmers to apply recommended agronomic practices and methods of constructing diffused light stores (DLS). A total of 185 stakeholders out of whom 58 were females and 127 males were participated on training with their percentage of $68.65 \%$ male and $31.35 \%$ of female respectively. From these training farmers got awareness on potato production and management as well as the way ones can store tubers for seed supply for wider potato production in target areas.

Table: Training Participant

\begin{tabular}{lllll}
\hline District & Participant & Male & Female & Total \\
\hline \multirow{2}{*}{ Sayo } & Farmer & 46 & 27 & 73 \\
& Expert & 9 & 4 & 13 \\
& DA'S & 9 & 7 & 16 \\
\hline L/Asabi & Farmer & 46 & 17 & 63 \\
& Expert & 8 & 1 & 9 \\
& DA'S & 9 & 2 & 11 \\
Total & & 127 & 58 & 185 \\
\hline Percentage & & $68.65 \%$ & $31.35 \%$ & $100 \%$ \\
\hline
\end{tabular}

\section{Conclusion}

Demonstration of agricultural technology among the important mechanism of enhancing adoption of agricultural technologies generated by agricultural research. To hasten this, we conducted the demonstration of the two top performed varieties for validation under farmers' management condition. The overall result obtained from this study revealed that the superiority of Belete variety over Gudane and local varieties in terms of biological criterions and farmers preference. Gudane variety showed strong attribute by the total number of marketable tubers. Generally, the research indicated that $56 \%$ of additional potato tubers can be put into farmers' food basket by production of Belete and Gudane varieties which are very important for reducing food insecurity in the study area dominated by cereal-based food. Mover over this, the research is evidenced as the best crop for diversification of farmers' income with intended profitability. Therefore, this result implies that researchers, policymakers, extension service providers and other concerned bodies should be given attention to increasing the adoption of improved Belete and Gudane varieties (Feleke et al., 2019)

\section{Acknowledgment}

This research was funded by Agricultural Growth Program II (AGP-II) and Oromia Agricultural Research Institute (IQQO). We are very grateful to the project and institute for financing this study for betterment of our farmer's livelihood.

\section{Declaration of conflict of interest}

The authors confidently declare that there is no any conflict of interest between authors.

\section{Reference}

Alo, S., and Geremew, D. (2021). Adaptability of Released Potato ( Solanum tuberosum L .) Varieties at Masha and Chena , South western. Agriculture and Soil Science, 4-8. https://doi.org/10.33552/WJASS.2021.06.000646

Amha, B., Bekele, G., \& Abate, M. (2019). Integrated evaluation of potato varieties in the highlands of Girar Jarso Woreda, North Shewa, Ethiopia. Journal of Plant Breeding and Crop Science, 11(4), 120-127. https://doi.org/10.5897/jpbcs2018.0751

Asresie Hassen, Alemu Worku, Molla Tafere, Abel Ahmed, Seferew Dagnew, Yihenew G.Sellasie, D. M. and T. A. (2015). Best Fit Practice Manual for potato prodution and utilization

Devaux, A., Kromann, P., \& Ortiz, O. (2014). Potatoes for Sustainable Global Food Security. Potato Research, 57(3-4), 185-199. https://doi.org/10.1007/s11540-014-9265-1

Emana, B., \& Nigussie, M. (2011). Potato Value Chain Analysis and Development in Ethiopia. 1-82. http://sweetpotatoknowledge.org/projects-initiatives/better-potato-for-a-better-life/resources/potato-valuechain-analysis-and-development-in-ethiopia.pdf

Feleke, A., Regasa, G., \& Muche, M. (2019). Factors influencing adoption of improved potato (Belete) variety: Evidence from Ethiopian smallholder farmers. Agraarteadus, 30(2), 85-92. https://doi.org/10.15159/jas.19.17

Hailu, M., Abebe, S., and Fikre, D. (2020). Demonstration of Improved Potato Varieties At Koffele. 7(3), 45-52. 
Helen Teshome. (2016). A review on potato (Solanum tuberosum L.) production situations in Ethiopia. Food Science and Quality Management, 57, 32-35.

Mumia, I, B., W. Muthomi, J., D. Narla, R., W. Nyongesa, M., \& M. Olubayo, F. (2018). Seed Potato Production Practices and Quality of Farm Saved Seed Potato in Kiambu and Nyandarua Counties in Kenya. World Journal of Agricultural Research, 6(1), 20-30. https://doi.org/10.12691/wjar-6-1-5

Jafar, M., Degefa, G., Benti, G., \& Wakgari, G. (2020). Participatory Variety Selection of Improved Potato ( Solanium tuberosum L ) Varieties in Harari People Regional State and Eastern Hararghe Zone. Journal of Plant Sciences, 8(6), 208-213. https://doi.org/10.11648/j.jps.20200806.13

Kassaw, A., Abera, M., \& Belete, E. (2021). The Response of Potato Late Blight to Potato varieties and Fungicide Spraying Frequencies at Meket, Ethiopia. Cogent Food and Agriculture, 7(1). https://doi.org/10.1080/23311932.2020.1870309

Kolech, S. A., Halseth, D., Perry, K., De Jong, W., Tiruneh, F. M., \& Wolfe, D. (2015). Identification of Farmer Priorities in Potato Production Through Participatory Variety Selection. American Journal of Potato Research, 92(6), 648-661. https://doi.org/10.1007/s12230-015-9478-0

Lupescu, M., and Zimmerman, J. (2015). Potatoes and Potato Products Annual. In USDA Global Agricultural Information Network.

Merga, B., \& Dechassa, N. (2019). Growth and Productivity of Different Potato Cultivars. Journal of Agricultural Science, 11(3), 528. https://doi.org/10.5539/jas.v11n3p528

MoA. (2018). Plant variety release, protection and seed quality control directorate. In Crop variety Register Issue number 21.

FAO. (2008a). International year of the potato, Potato and gender, Rome, Italy

FAO, (2008b). The global potato economy. FAO's Trade and Markets Division, 2. http://www.fao.org/potato2008/en/potato/IYP-3en.pdf

Tessema, L., Mohammed, W., and Abebe, T. (2020). Evaluation of Potato ( Solanum tuberosum L.) Varieties for Yield and Some Agronomic Traits . Open Agriculture, 5(1), 63-74. https://doi.org/10.1515/opag-20200006 